\title{
ANTIBACTERIAL ACTIVITIES OF MULTI DRUG RESISTANT MYROIDES ODORATIMIMUS BACTERIA ISOLATED FROM ADULT FLESH FLIES (DIPTERA: SARCOPHAGIDAE) ARE INDEPENDENT OF METALLO BETA-LACTAMASE GENE
}

\author{
M.S. Dharne ${ }^{1,3}$; A.K. Gupta ${ }^{1}$; A.Y. Rangrez ${ }^{1}$; H.V. Ghate ${ }^{2}$; M.S. Patole ${ }^{1}$; Y.S. Shouche ${ }^{1 *}$ \\ ${ }^{1}$ Molecular Biology Unit, National Centre for Cell Science, Ganeshkhind, Pune-411 007, Maharashtra, India; ${ }^{2}$ Department of \\ Zoology, Modern College of Arts, Science and Commerce, Shivajinagar, Pune-411 005, Maharashtra, India; ${ }^{3}$ Present address: \\ Produce and Quality and Safety Laboratory, Henry A. Wallace Beltsville Agricultural Research Center, Agricultural Research \\ Service, 10300 Baltimore Avenue, Beltsville, Maryland 20705, United States
}

Submitted: August 21, 2007; Returned to authors for corrections: December 07, 2007; Approved: May 04, 2008.

\begin{abstract}
Flesh flies (Diptera: Sarcophagidae) are well known cause of myiasis and their gut bacteria have never been studied for antimicrobial activity against bacteria. Antimicrobial studies of Myroides spp. are restricted to nosocomial strains. A Gram-negative bacterium, Myroides sp., was isolated from the gut of adult flesh flies (Sarcophaga sp.) and submitted to evaluation of nutritional parameters using Biolog GN, 16S rRNA gene sequencing, susceptibility to various antimicrobials by disc diffusion method and detection of metallo $\beta$ lactamase genes (TUS/MUS). The antagonistic effects were tested on Gram-negative and Gram-positive bacteria isolated from human clinical specimens, environmental samples and insect mid gut. Bacterial species included were Aeromonas hydrophila, A. culicicola, Morganella morganii subsp. sibonii, Ochrobactrum anthropi, Weissella confusa, Escherichia coli, Ochrobactrum sp., Serratia sp., Kestersia sp., Ignatzschineria sp., Bacillus sp. The Myroides sp. strain was resistant to penicillin-G, erythromycin, streptomycin, amikacin, kanamycin, gentamycin, ampicillin, trimethoprim and tobramycin. These strain showed antibacterial action against all bacterial strains except $W$. confusa, Ignatzschineria sp., A. hydrophila and M. morganii subsp. sibonii. The multidrug resistance of the strain was similar to the resistance of clinical isolates, inhibiting growth of bacteria from clinical, environmental and insect gut samples. The metallo $\beta$-lactamase (TUS/MUS) genes were absent, and resistance due to these genes was ruled out, indicating involvement of other secretion machinery.
\end{abstract}

Key-words: Flesh fly, Myroides sp., 16S rRNA, antibacterial activity, metallo beta-lactamase

\section{INTRODUCTION}

The genus Flavobacterium was created in 1923 and since then, the taxonomy of this genus has undergone substantial changes, especially for strains belonging to the former Flavobacterium odoratum ( $F$. odoratum) species. The $F$. odoratum was further classified afterwards in a separate genus on the basis of its unique phenotypic features. Strains of this species, differing from most Flavobacterium species in being nonsaccharolytic, fail to produce indole (10). Using 16S rRNA sequencing $F$. odoratum was shown to occupy an independent taxonomic position in the genus Flavobacterium (34). Finally, the genus Myroides was created for organisms removed from the genus Flavobacterium on the basis of hybridization experiments and phenotypic characteristics and two species have been delineated; Myroides odoratus (M. odoratus) and Myroides odoratimimus (M. odoratimimus) (34). Antimicrobial properties of Flavobacteria are well studied $(5,12)$ up to molecular and kinetic level (18). Bacteria Myroides spp. are aerobic, yellowpigmented, Gram-negative rods that grow at both room

*Corresponding Author. Mailing address: Molecular Biology Unit, National Centre for Cell Science, Ganeshkhind, Pune-411 007, Maharashtra, India. Tel.: (+91) 20-25708050, Fax: (+91) 20-25692259. E-mail: yogesh@nccs.res.in 
temperature and $37^{\circ} \mathrm{C}$. They are habitat-specific organisms, like other members of the Flavobacteriaceae family, and are found in wet environments (12), insect guts (31) and sea water $(19,37)$. Strains of $M$. odoratus and $M$. odoratimimus are sources of nosocomial infections in humans and behave like low-grade opportunistic pathogens. Myroides was identified as a cause of surgery wound and urinary tract infections, septicemia, pneumonia, meningitis, fasciitis, and ventriculitis (36). Although the antibiotic resistance patterns of Flavibacterium and Myroides strains shows variable susceptibility to beta-lactams ( $\beta$-lactams) (12), there is constant decrease in susceptibility to cephalosporin and imipenem. The $\beta$-lactamases produced by Gram negative and Gram positive bacteria play a significant role in resistance against $\beta$-lactam antibiotics but with variable activities $(14,18)$. Previously, M. odoratus was isolated from lepidopteran gut and it was hypothesized that this bacteria may be involved in the production of some biosurfactants (31). However, there is not a single report of isolation as well as antimicrobial studies on M. odoratimimus of insect gut origin, since all previous reports are from clinical samples. It is well known fact that Sarcophagids secrete antibacterial proteins, inhibiting entrance of pathogens in their gut contents (1). Moreover these flies have also been linked with myiasis like infections (3).

During the course of insect gut microbiota studies, we isolated a Myroides sp. from adult flesh flies (Diptera: Sarcophagidae) collected from chicken bait and characterized by various genotypic and biochemical methods. The antimicrobial susceptibility testing and antimicrobial activity of this bacterium has been discussed. Bacterial isolates belonging to different lineages (data not shown) were also isolated from larval stages of these flies. Since Myroides sp. was exclusively documented in adults and in flies' guts and previously documented for antimicrobial action, here we present the data from adults only.

\section{MATERIALS AND METHODS}

\section{Isolation of bacteria from flesh flies guts}

The larval flesh flies were reared on chicken flesh kept in wire mesh cages to obtain adult flies and a few adult flies were collected directly from the flesh market in Pune, India, using insect net and brought alive to the laboratory in PET jars during June 2007. To achieve this, partly cooked fresh chicken flesh was kept in open petridish in the window of the laboratory to attract the flies. After the visit of a few sarcophagid flies, the flesh was transferred to wire mesh cages or transparent PET bottles covered with wire mesh and the larvae were allowed to grow to maturity and pupate at room temperature. The flies that hatched were collected and used in the studies. All this was done in Pune metropolis, Maharashtra State, India. About 10 flies were tested. Gut contents were aseptically excised and placed in physiological saline. The minced gut suspension was poured on Luria agar (USB) supplemented with 5\% defibrinated and inactivated human blood. The plates were incubated aerobically at $28^{\circ} \mathrm{C}$ and $37^{\circ} \mathrm{C}$ for $18-24$ hours. The bacteria (named as FFA2) with characteristic yellow pigmentation were Gram stained, sub cultured on blood agar plates and stored in $80 \%$ glycerol solution at $-80^{\circ} \mathrm{C}$ following the standard protocol mentioned elsewhere. However, we present the data from adult stage in the present investigation.

\section{PCR amplification, sequencing and phylogenetic analysis}

Genomic DNA from the broth culture was prepared according to Sambrook et al., 1993 (28). The $1500 \mathrm{bp}$ fragment of 16S rRNA gene was amplified from extracted DNA using bacterial universal primers specific to $16 \mathrm{~S}$ rRNA gene, primer 27F, 5'-CCA GAG TTT GAT CMT GGC TCA G-3' (binding at $5^{\text {th }}$ base of Escherichia coli numbering system of Brosius et al. 1978 (4)) and primer 1525R, 5'-TTC TGC AGT CTA GAA GGA GGT GWT CCA GCC -3' (binding at $1495^{\text {th }}$ position of E. coli). PCR and DNA sequencing protocols have been described earlier (23). The 16S rRNA gene sequence of strain FFA2 was compared with the sequences obtained from GenBank. Sequences were aligned with Clustal W software (32) and evolutionary distances along with Knuc value (16) were generated. Alignment gaps and ambiguous bases were not considered while comparing 1349 nucleotides of 16S rRNA gene. A phylogenetic tree was constructed by using neighbourjoining method (27) and Kimura 2 parameter in MEGA v3.1 (16). The topology of the phylogenetic tree was evaluated by the bootstrap re-sampling method of Felsenstein (8) with 1000 replicates (Fig. 1).

\section{Biochemical identification of isolate FFA2 by BIOLOG-GN}

Nutritional parameters of strain FFA2 was determined by using BIOLOG-GN microplates as described in Yoon et al., 2006. The protocols were followed as per manufacturers' instructions.

\section{Antibiotic sensitivity analysis of FFA2}

The antimicrobial susceptibility testing was performed using a broth dilution method on Mueller Hinton agar (Hi-Media Laboratories, India) as recommended by National Committee for Clinical Laboratory Standards (NCCLS) (22) with various antimicrobial agents including those described by Holmes et al. 1979 (12). In all, 43 antibiotics were tested for antibiotic sensitivity on FFA2.

\section{Antimicrobial activity testing using agar well method and paper disk diffusion method}

The antibacterial activity of isolate FFA2 was checked by plating reference isolates (see Table 1 for details) individually on Luria broth and sub-cultured on Mueller Hinton agar (Hi 


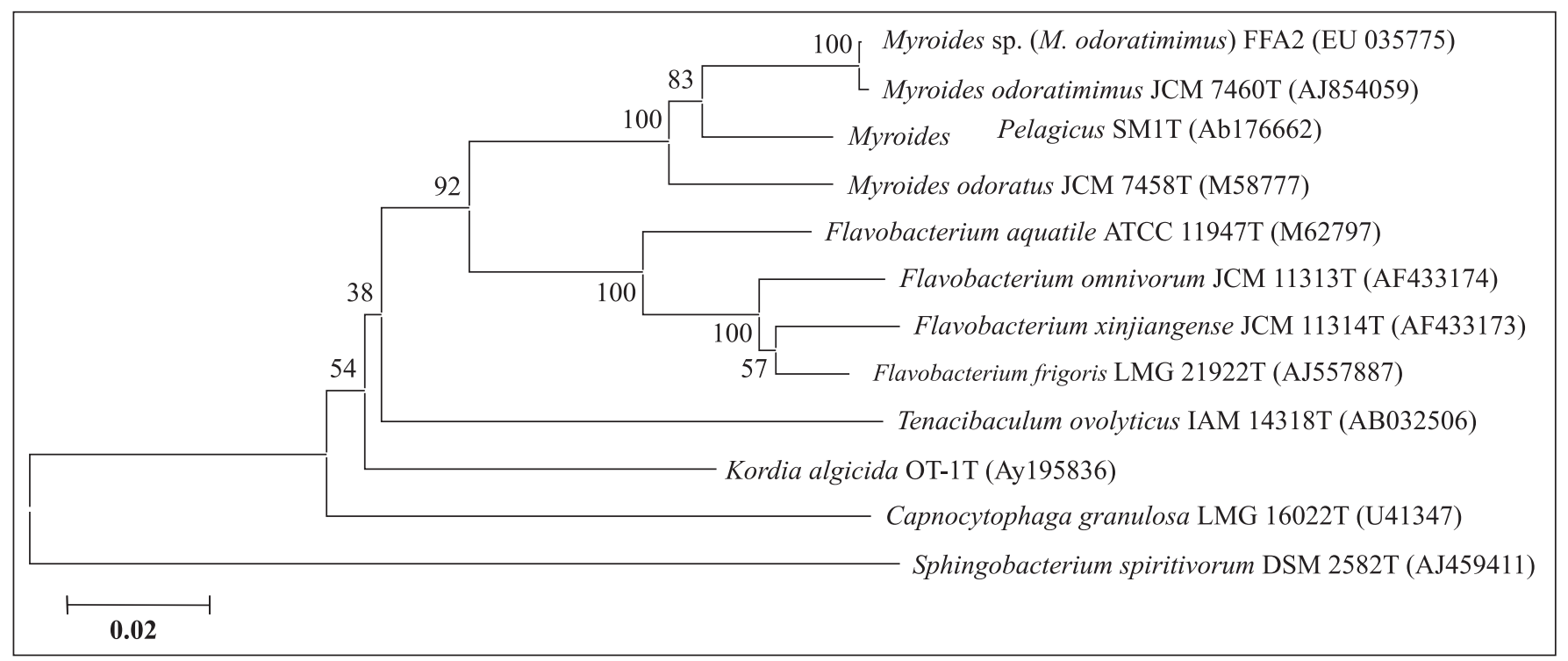

Figure 1. Phylogenetic affiliation of Myroides sp. strain FFA2 isolated from adult flesh fly gut Sarcophaga sp. (Diptera: Sarcophagidae). Neighbor joining tree constructed in MEGA v3.1 using Kimura 2 parameter using Myroides sp. isolate FFA2 and related bacteria based on 16S rRNA gene sequence comparisons. Sphingobacterim pritovorum DSM $2050^{\mathrm{T}}$ was used as an outgroup. Bootstrap replicates of 1000 numericals are shown on nodes. Bar 0.01 indicates nucleotide substitutions per site.

Table 1. Comparative biochemical characteristics of Myroides sp. strain FFA2, M. odoratimimus JCM 7460T(Holmes et al., 1979) and M. odoratus JCM 7458T(Vancanneyt et al., 1996).

\begin{tabular}{|c|c|c|c|}
\hline Characteristic & $\begin{array}{l}\text { Myroides sp. } \\
\text { Isolate FFA2 }\end{array}$ & $\begin{array}{l}\text { M. odoratimimus } \\
\text { JCM } 7460^{\mathrm{T}}\end{array}$ & $\begin{array}{l}\text { M. odoratus } \\
\text { JCM } 7458^{\mathrm{T}}\end{array}$ \\
\hline Source & arcophaga sp. & Wound swab & Faeces \\
\hline Cell morphology & Short rods & Rods & Long rods \\
\hline Cell diameter (um) & $2.5-3$ & $3.5-4$ & $11-12$ \\
\hline Cell width (um) & $0.2-0.3$ & $0.2-0.3$ & $0.2-0.3$ \\
\hline Pigmentation & Yellow & Pale yellow & Yellow \\
\hline $\mathrm{NaCl}$ range & $0-7$ & $0-6$ & $0-5$ \\
\hline $\mathrm{pH}$ range & $6-9$ & $6-9$ & $6-9$ \\
\hline Catalase & + & + & + \\
\hline Urease & + & + & + \\
\hline Nitrate reduction & + & + & + \\
\hline \multicolumn{4}{|l|}{ Activity of: } \\
\hline Esterase (C4) & + & + & + \\
\hline Esterase lipase (C8) & + & + & + \\
\hline \multicolumn{4}{|l|}{ Utilization of: } \\
\hline L-Histidine & + & + & + \\
\hline$\alpha$-Hydroxybutyric acid & - & - & + \\
\hline Succinamic acid & + & + & + \\
\hline Urocanic acid & + & + & + \\
\hline
\end{tabular}

Media Laboratories, India). Macerated adult gut content was also tested for antimicrobial activity. Each reference strain was plated at equal bacterial cell density, determined by taking optical density (OD) at $600 \mathrm{~nm}$ in spectrophotometer (BioRad, Hercules, USA) to get mat growth followed by the filter paper disk soaked in FFA2 culture was placed at the centre of each plate. Simultaneously, FFA2 bacterial suspension was also added in the wells cut on agar. All the plates were incubated at $28^{\circ} \mathrm{C}$ and $37^{\circ} \mathrm{C}$ for 24 h. Bacteria strains were glycerol preserved at $-80^{\circ} \mathrm{C}$.

\section{Detection of TUS/MUS genes in Myroides sp.}

In order to check presence of $\beta$-lactamase gene (1500 bp), which is known to be responsible for variable resistance pattern to $\beta$-lactam antibiotics and decreased susceptibility to carbapenems in various Flavobacteria, the PCR was performed by the specific primers spanning entire gene along with open reading frame (ORF) (Mammeri et al. 2002). The PCR was carried out in $25 \mathrm{ul}$ volume containing $2.5 \mathrm{mM}$ nucleotides (dNTPs), 10X PCR buffer, 10 $\mathrm{pM}$ of forward and reverse primers, $1 \mathrm{U}$ of Taq DNA polymerase and $10 \mathrm{ng}$ genomic DNA. Cycling parameters were initial denaturation at $94^{\circ} \mathrm{C}$ for $1 \mathrm{~min}$, annealing at $55^{\circ} \mathrm{C}$ for $1 \mathrm{~min}$ and extension at $72^{\circ} \mathrm{C}$ for 
$1 \mathrm{~min}$, and the cycles were repeated for 35 times. Amplicons were electrophoresed in $1 \%$ agarose gel followed by their visualization under UV light.

\section{RESULTS}

16S rRNA gene sequence of strain FFA2 (GenBank accession number EU 035775) showed highest similarities to the sequences of M. odoratimimus JCM $7460^{\mathrm{T}}$, AJ854059 $(100 \%)$ and $M$. odoratus JCM $7458^{\mathrm{T}}$, M58777 (95\%) and M. pelagicus IAM $15337^{\mathrm{T}}, \mathrm{AB} 176662(96 \%)$. The phylogenetic tree showed that the strain FFA2 clustered with $M$. odoratimimus JCM $7460^{\mathrm{T}}$ with $100 \%$ bootstrap support. These results indicated that FFA2 strain is M. odoratimimus JCM $7460^{\mathrm{T}}$ (12) of genus Myroides. Biochemical characteristics of strain FFA2 and $M$. odoratimimus JCM $7460^{\mathrm{T}}$ were compared. Strain FFA2 was able to grow at 7 $9 \% \mathrm{NaCl}$, whereas previously reported clinical isolates could tolerate $5-6 \% \mathrm{NaCl}$ concentration and recently reported isolate M. pelagicus IAM $15337^{\mathrm{T}}$ could tolerate $9 \% \mathrm{NaCl}$. Moreover, the strain FFA2 showed some biochemical characters similar to M. odoratimimus as shown in Table 2.

The strain FFA2 was resistant to antimicrobials like gentamycin $(10 \mathrm{mcg})$, ceftriazone $(30 \mathrm{mcg})$, cefaclor $(30 \mathrm{mcg})$, penicillin $\mathrm{G}$ (10 Units), erythromycin (15 mcg), aztreonam (30 $\mathrm{mcg}$ ), streptomycin ( $25 \mathrm{mcg}$ ), amikacin ( $30 \mathrm{mcg}$ ), co-trimoxazole (25 mcg), kanamycin (30 mcg), ampicillin (10 mcg), ceftazidime
(30 mcg), netillin (30 mcg), ticarciliin (75 mcg), trimethoprim (5 $\mathrm{mcg}$ ), suplhomethoxazole $(25 \mathrm{mcg})$, cephalothin $(30 \mathrm{mcg})$, cefoxitin (30 mcg), tobramycin (10 mcg), piperacillin (100 mcg), teicoplanin (30 mcg) (Table 3). Whereas, isolate was sensitive to antimicrobials like gatifloxacin $(30 \mathrm{mcg})$, vancomycin $(30 \mathrm{mcg})$, ofloxacin (5 g), sparfloxacin (5 mcg), azithromycin (15 mcg), doxycycline hydrochloride (30 mcg), chloramphenicol (30 mcg), tetracyclin (30 mcg), ciprofloxacin (5 mcg), nitrofurantoin (300 $\mathrm{mcg}$ ), norfloxacin (10 mcg) by disk diffusion method.

Gram negative Myroides sp. isolated in present case exhibited antibacterial activity against bacteria like $O$. anthropi $\mathrm{LMG} 3331^{\mathrm{T}}$ (clinical isolate), A. culicicola MTCC $3249^{\mathrm{T}}$ (mosquito gut isolate), E. coli JM109 (Genetically engineered strain), Serratia sp. strain ST11 isolated from beetle gut (Stibara sp.), Kerstersia sp. strain HF2 (isolated from Musca domestica gut), Bacillus sp. strain FFL7 (isolated from flesh fly larvae). Whereas, it could not inhibit the growth of clinical isolates like M. morganii subsp. sibonii CDC 8103-85, A. hydrophila ATCC 7966, Ignatzschineria sp. and O. intermedium (MTCC 4990) strain M86 and Gram positive bacteria like $W$. confusa ATCC $14434^{\mathrm{T}}$. Minced gut content inhibited growth of only two bacterial strains namely, Bacillus sp. isolate FFL7 and Kerstersia sp. strain HF2. Strain FFA2 found to be negative for the presence of metallo $\beta$-lactamase (TUS/MUS) gene (1.5 $\mathrm{Kb}$ ), which is known to be involved in variable resistance to $\beta$-lactams and carbapenems.

Table 2. Bacterial strains used in the study along with their source of isolation, type strain, 16S rRNA gene accession numbers available in GenBank.

\begin{tabular}{|c|c|c|c|c|c|}
\hline Bacterial Strains & $\begin{array}{l}\text { Type } \\
\text { strain }\end{array}$ & $\begin{array}{c}\text { GenBank } \\
\text { accession } \\
\text { number }\end{array}$ & Source of isolation & $\begin{array}{c}\text { Pathogenic } \\
\text { (Yes/Not } \\
\text { proved) }\end{array}$ & Reference \\
\hline Myroides sp. strain FFA2 & Not assigned & EU035775 & $\begin{array}{l}\text { Flesh fly (Sarcophaga sp.) } \\
\text { adult gut }\end{array}$ & $\mathrm{N}$ & This paper \\
\hline \multicolumn{6}{|l|}{ Aeromonas hydrophila } \\
\hline Hybridization group (HG) 1 & ATCC $7966^{\mathrm{T}}$ & X60404 & Human clinical specimen & $\mathrm{Y}$ & (30) \\
\hline Aeromonas culicicola subsp. SH & MTCC $3249^{\mathrm{T}}$ & AY130991 & Mosquito (A. aegyptii) midgut & $\mathrm{N}$ & (23) \\
\hline Morganella morganii subsp. & & & & & \\
\hline sibonii Biogroup 2 & DSM14850 & DQ358146 & Human clinical specimen & $\mathrm{Y}$ & $(15)$ \\
\hline Ochrobactrum anthropi & LMG $3331^{\mathrm{T}}$ & AM114398 & Human clinical specimen & Y & (11) \\
\hline Weissella confusa NCDO 5186 & ATCC $14434^{\mathrm{T}}$ & $\mathrm{X} 52567$ & Grass silage & $\mathrm{N}$ & (13) \\
\hline Ochrobactrum sp. strain M86 & MTCC $4990^{\mathrm{T}}$ & DQ100421 & Clinical isolate & $\mathrm{N}$ & (7) \\
\hline Escherichia coli strain JM109 & Not assigned & AB305017 & Genetically engineered & $\mathrm{N}$ & Promega \\
\hline Serratia sp. strain ST11 & Not assigned & EF600986 & Beetle (Stibara sp.) midgut & $\mathrm{N}$ & Unpublished \\
\hline Kestersia sp. strain HF2 & Not assigned & Awaited & House fly (Musca domestica) gut & $\mathrm{N}$ & Unpublished \\
\hline Ignatzschineria sp. strain FFA1 & Not assigned & EU008088 & Flesh fly (Sarcophaga sp.) adult gut & $\mathrm{N}$ & Unpublished \\
\hline Bacillus sp. strain FFL7 & Not assigned & Awaited & Flesh fly (Sarcophaga sp.) larval gut & ut $\mathrm{N}$ & Unpublished \\
\hline
\end{tabular}


Table 3. The diameters of zone of inhibitions of antibacterial activity (in $\mathrm{mm}$ ) of FFA2 with other bacterial strains included in the study.

\begin{tabular}{lccc}
\hline \multicolumn{1}{c}{ Bacterial Strains tested } & $\begin{array}{c}\text { Zone of inhibition size } \\
(\mathrm{mm}) \text { due to } \\
\text { Myroides sp. FFA2 }\end{array}$ & $\begin{array}{c}\text { Growth inhibited } \\
\text { Myroides sp. } \\
\text { by (Yes/No/Weakly) }\end{array}$ & $\begin{array}{c}\text { Growth inhibited } \\
\text { by Gut content } \\
\text { (Yes/No/Weakly) }\end{array}$ \\
\hline Aeromonas hydrophila Hybridization group (HG) 1 & 7 & $\mathrm{~N}$ & $\mathrm{~N}$ \\
Aeromonas culicicola subsp. SH & 19 & $\mathrm{Y}$ & $\mathrm{Y}$ \\
Morganella morganii subsp. sibonii Biogroup-2 & 10 & $\mathrm{~N}$ & $\mathrm{~N}$ \\
Ochrobactrum anthropi & 20 & $\mathrm{Y}$ & $\mathrm{Y}$ \\
Weissella confusa & 7 & $\mathrm{~N}$ & $\mathrm{~N}$ \\
Ochrobactrum sp. strain M86 & 9 & $\mathrm{Y}$ & $\mathrm{Y}$ \\
Serratia sp. strain ST11 & 19 & $\mathrm{Y}$ & $\mathrm{Y}$ \\
Kestersia sp. strain HF2 & 21 & $\mathrm{~N}$ & $\mathrm{~N}$ \\
Ignatzschineria sp. strain FFA1 & 8 & $\mathrm{Y}$ & $\mathrm{Y}$ \\
Bacillus sp. strain FFL7 & 19 & $\mathrm{Y}$ & $\mathrm{Y}$ \\
Escherichia coli strain JM109* & 18 & & \\
\hline
\end{tabular}

${ }^{*}$ Values were compared with NCCLS recommendations with Escherichia coli as a control.

\section{DISCUSSION}

Flavobacterium species (M. odoratus and M. odoratimimus), glucose-non fermenting, Gram-negative rods, are widely occurring in natural ecosystems, like soil, fresh and marine waters, in foods and in sewage treatment plants. As Holmes (12) stated, "The problem of treating infections caused by gentamicin-resistant Flavobacterium spp. remains unsolved" looks valid statement. As a result of the wide variation in antimicrobial susceptibility shown by different species, a test on susceptibility to different antibacterial agents is essential in order to select an adequate therapy. The marked multiple drug resistance observed in some species, prompts the need to develop new antimicrobial agents active against this group of bacteria and to search for synergistic combinations. Resistance of nosocomial originated Flavobacteria to wide range of antimicrobial agents like gentamycin, tobramycin, amikacin and carbenicillin to which Gram-negative, non fermentative bacteria might be expected to be susceptible to suggests that any infections due to these species would prove difficult to treat, in case of clinical cases involving systemic infections $(9,12)$.

The $\beta$-lactamases produced by Gram-negative and Grampositive bacteria play vital role in resistance against $\beta$-lactam antibiotics (29). Mammeri et al. (18) proposed that although Myroides spp. possess metallo $\beta$-lactamases, it is difficult to predict the role of $\beta$-lactam resistance in pathogenecity and epidemiology. This might be due to the reason that since metalloenzymes expressed in E. coli gives much lower level of $\beta$-lactam resistance as compared to original producers. Such phenomenon is observed due to combined biosynthesis of carbapenem derivatives and carbapenem hydrolyzing $\beta$ lactamases as observed in Streptomyces sp. Bacteria isolated from lepidopteran gut are known to produce biosurfactants and act as plant volatiles; however, their exact role is not yet understood, but it is hypothesized that they might have the same role as in case of mammals (19). Present investigation is the first documented evidence of presence of $M$. odoratimimus in adult flesh flies (Sarcophagidae) of diptera. Prevoiusly, a Myroides sp. (M.odoratus) was isolated from lepidopteran guts. We for the first time investigated the antimicrobial activities of our Myroides sp. in various clinical, environmental and insect gut bacterial isolates. Myroides bacteria isolated from flesh fly guts showed resistance to various antimicrobials including the one which were described in Holmes et al., 1979 and proved to be multi drug resistant. Although, $\beta$-lactam resistance has been linked with presence of $\beta$-lactamase genes, according to our interpretation, the Myroides sp., in our samples (FFA2) lacked presence of TUS and MUS genes (18). Strain FFA2 isolated from flesh fly gut could not inhibit the growth of Gram positive bacteria like Weissella confusa, which was isolated from food samples (2). The growth of Gram negative bacteria like $O$. anthropi LMG $3331^{\mathrm{T}}$ (clinical isolate), A. culicicola MTCC $3249^{\mathrm{T}}$ (mosquito gut isolate), E. coli JM109 (Genetically engineered strain) was inhibited, even though these bacteria possess $\beta$-lactamase and conjugation related secretion mechanisms $(11,21,24)$. Interestingly, FFA2 strain inhibited growth of some of the recently isolated gut bacteria from insects (unpublished data) like Serratia sp. strain ST11 isolated from beetle gut (Stibara sp.), Kerstersia sp. strain HF2 (isolated from Musca domestica gut), Bacillus sp. strain FFL7 (isolated from flesh fly larvae). Bacteria belonging to genera like Serratia, Kerstersia and Bacillus are well documented for their pathogeneticity from various environments $(6,17,25)$. Some of the clinical isolates like $M$. 
morganii subsp. sibonii CDC 8103-85, A. hydrophila ATCC 7966 and $O$. intermedium (MTCC 4990) strain M86 could not be inhibited by the strain FFA2. The M. morganii, A. hydrophila, Ochrobactrum spp. are well known for $\beta$-lactamase gene $(21,33,35)$. Recently isolated strain of Ignatzschineria sp. from insect gut (unpublished data) was resistant to the antimicrobial action of Myroides sp. Interestingly, Ignatzschineria sp (formerly Schineria) is a bacterium already known to be associated with human infections (20). Further, extract of gut content also inhibited the growth of Bacillus sp. and Kerstersia sp. indicating the production of antibacterial compounds by this fly in order to survive and combat the infestations due to bacteremia by other bacterial pathogens (1). However, why the Myroides sp. isolated in the present investigation did not inhibit growth of some bacteria isolated from same fly, however, it could be the result of interaction between flesh fly and Myroides sp., which is unknown, which might have conferred resistance. We supported this fact that there must be some reason to believe due to association between fly and bacteria, due to which survival is possible in the fly gut irrespective of providing resistance to the host (i.e. fly) but in vitro activity exists outside the gut.

It is noteworthy that Myroides sp. isolated in present case, exhibited broad range of antibiotic resistance and so also antimicrobial activity against various pathogens. It is well established fact that the resistance to various antimicrobials may be due to presence of some virulence gene or involvement of secretion machinery of multi drug efflux proteins $(12,24)$. Increased antibiotic resistance in such bacteria where $\beta$ lactamase gene subunit is lacking, is mediated by acquiring resistance mechanisms through mutations in bacterial genome or by gaining additional genes through horizontal gene transfer or by physiology dependent resistance. Moreover, bacteria have intrinsic resistance mechanisms that are often not detected in standard antibiotic sensitivity tests performed at laboratory level (26). However, Myroides are linked with low virulence and mortality when it comes to clinical level. Here we propose that some antibiotics like gatifloxacin, vancomycin, ofloxacin, sparfloxacin, azithromycin, doxycycline, chloramphenicol, tetracyclin, ciprofloxacin, nitrofurantoin and norfloxacin could be useful while treating the Myroides infections caused by 'visiting' dipteran flies. Since flesh flies are vectors for myiasis like infections, we would like to warn that the consumption of meat infected with multidrug resistant $M$. odoratimimus carried by flesh flies might lead to severe consequences.

\section{ACKNOWLEDGEMENTS}

Our sincere thanks are due to Department of Biotechnology, New Delhi, India for providing funding to YS and HVG and fellowships to MD, AG and AR. We express gratitude towards the Director, National Centre for Cell Science (NCCS) Pune, India and Principal at Modern College of Arts, Science and Commerce, Pune. Authors are indebted to all those who shared reference bacterial strains for the present study. These include, Caroline O'Hara (CDC, Atlanta) for M. morganii biogroup-2 CDC 810385, Ignacio Moriyon (Department of Microbiology, University of Navarra, Spain) for O. anthropi LMG 3331, Rasesh Parikh and Lokesh Sharma (both from NCCS) for sharing actively growing cultures of $M$. morganii subsp. sibonii and $W$. confusa respectively) for providing information, suggestions and critical comments about bacterial strains used in study. Finally special thanks to Aditya Takale (Modern College) for providing reared specimens of Sarcophaga sp. All authors have carefully read and approved the manuscript for submission.

\section{RESUMO}

\section{Atividades antibacterianas de Myroides odoratimimus isolada de moscas varejeiras adultas (Diptera: Sarcophagidae) são independentes do gene metalo beta lactamase}

Moscas varejeiras (Diptera: Sarcophagidae) são causa conhecida de míáase e as bactérias de seus intestinos nunca foram estudadas quanto à atividade antibacteriana. Estudos antimicrobianos de Myroides spp restringem-se à cepas hospitalares. Uma bactéria Gram negativa, Myroides sp, foi isolada do intestino de moscas varejeiras adultas (Sarcophaga sp) e submetida à avaliação de parâmetros nutricionais pelo sistema BIOLOG GN, ao sequenciamento genético 16S rRNA, à sensibilidade a vários antimicrobianos pelo método de difusão de discos e à detecção dos genes de metalo beta lactamases (TUS/MUS). Os efeitos antagonistas foram testados contra bactérias Gram negativas e Gram positivas isoladas de material clínico humano, amostras ambientais e intestino do inseto. As espécies bacterianas incluíram Aeromonas hydrophila, A. culicicola, Morganella morganii subsp sibonii, Ochrobactrum anthropi, Weissella confusa, Escherichia coli, Ochrobactrum sp, Serratia sp, Kestersia sp, Ignatzschineria sp e Bacillus sp. A cepa Myroides sp foi resistente à penicilina G, eritromicina, estreptomicina, amicacina, canamicina, gentamicina, ampicilina, trimetoprim e tobramicina. Esta cepa apresentou atividade antimicrobiana contra todas as cepas exceto W.confusa, Ignatzschineria sp, A. hydrophila e M. morgani subsp sibonii. A resistência múltipla da cepa foi semelhante à de isolados clínicos, inibindo bactérias das amostras clínicas, ambientais e do intestino do inseto. Os genes de metalo beta lactamases (TUS/MUS) estavam ausentes, excluindo-se a resistência mediada por esses genes, o que indica o envolvimento de um mecanismo alternativo de secreção.

Palavras-chave: Mosca varejeira, Myroides sp, atividade antimicrobiana, metalo beta lactamase 


\section{REFERENCES}

1. Ando, K.; Natori, S. (1988). Inhibitory effect of sarcotoxin IIA, an antibacterial protein of Sarcophaga peregrina, on growth of Escherichia coli. J. Biochem., (Tokyo), 103 (4), 735-739.

2. Bjorkroth, K.J.; Schillinger, U.; Geisen, R.; Weiss, N.; Hoste, B.; Holzapfel, W.H.; Korkeala, H.J.; Vandamme, P. (2002). Taxonomic study of Weissella confusa and description of Weissella cibaria $\mathrm{sp}$. nov., detected in food and clinical samples. Int. J. Syst. Evol. Microbiol., 52, 141-148.

3. Braverman, I.; Dano, I.; Saah, D.; Gapany, B. (1994). Aural myiasis caused by flesh fly larva, Sarcophaga haemorrhoidalis. J. Otolaryngol., 23 (3), 204-205.

4. Brosius, J.; Palmer, M.L.; Kennedy, P.J.; Noller, H.F. (1978). Complete nucleotide sequence of a 16S ribosomal RNA gene from Escherichia coli. Proc. Natl. Acad. Sci., U S A., 75 (10), 48014805.

5. Chang, J.C.; Hsueh, P.R.; Wu, J.J.; Ho, S.W.; Hsieh, W.C.; Luh, K.T. (1997). Antimicrobial susceptibility of flavobacteria as determined by agar dilution and disk diffusion methods. Antimicrob. Agents Chemother., 41 (6), 1301-1306.

6. Coenye, T.; Vancanneyt, M.; Cnockaert, M.C.; Falsen, E.; Swings, J.; Vandamme, P. (2003). Kerstersia gyiorum gen. nov., sp. nov., a novel Alcaligenes faecalis-like organism isolated from human clinical samples, and reclassification of Alcaligenes denitrificans Ruger and Tan 1983 as Achromobacter denitrificans comb. nov. Int. J. Syst. Evol. Microbiol., 53 (Pt 6), 1825-1831.

7. Dharne, M.S.; Misra, S.P.; Misra, V.; Dwivedi, M.; Patole, M.S.; Shouche, Y.S. Isolation of urease positive Ochrobactrum intermedium in the stomach of Non-ulcer dyspeptic patient from north India. J. Microbiol. Immunol. Infect., In Press.

8. Felsenstein, J. (1985). Confidence limits on phylogenies: an approach using the bootstrap. Evolution, 39, 783-791.

9. Green, B.T.; Green, K.; Nolan, P.E. (2001). Myroides odoratus cellulitis and bacteremia: case report and review. Scand. J. Infect. Dis., 33 (12), 932-934.

10. Holmes, B.; Owen, R.J.; McMeekin, T.A. (1984). Genus Flavobacterium. In: N.R. Krieg and J.G. Holt (ed.), Bergey's manual of systematic bacteriology. The Williams and Wilkins Co., Baltimore, Md., v. 1, 353-361.

11. Holmes, B.; Popoff, M.; Kiridjian, M.; Kersters, K. (1988). Ochrobactrum anthropi gen. nov., sp. nov. from human clinical specimens and previously known as group Vd. Int. J. syst. bacteriol., $38,406-416$.

12. Holmes, B.; Snell, J.J.S.; Lapage, S.P. (1979). Flavobacterium odoratum: a species resistant to a wide range of antimicrobial agents. J. Clinical. Pathol., 32, 73-77.

13. Holzapfel, W.; Kandler, O.; Holzapfel, W.; Kandler, O. (1969). Zur Taxonomie der Gattung Lactobacillus Beijerinck. VI. Lactobacillus coprophilus subsp. confusus nov. subsp., eine neue Unterart der Untergattung Betabacterium. Zentralbl. Bakteriol. Parasitenkd., Abt. II $123,657-666$.

14. Hummel, A.S.; Hertel, C.; Holzapfel, W.H.; Franz, C.M. (2007). Antibiotic resistances of starter and probiotic strains of lactic acid bacteria. Appl. Environ. Microbiol., 73 (3), 730-739.

15. Jensen, K.T.; Frederiksen, W.; Hickeman-Brenner, F.W.; Steigerwalt, A.G.; Riddle, C.F.; Brenner, D.J. (1992). Recognition of Morganella subspecies, with proposal of Morganella morganii subsp. morganii subsp. nov. and Morganella morganii subsp. sibonii subsp. nov. Int. J. Syst. Bacteriol., 42, 613-620.

16. Kimura, M. (1980). A simple method for estimating evolutionary rates of base substitutions through comparative studies of nucleotide sequences. J. Mol. Evol., 16, 111-120.

17. Luna, V.A.; King, D.S.; Gulledge, J.; Cannons, A.C.; Amuso, P.T.; Cattani, J. (2007). Susceptibility of Bacillus anthracis, Bacillus cereus,
Bacillus mycoides, Bacillus pseudomycoides and Bacillus thuringiensis to 24 antimicrobials using Sensititre (R) automated microbroth dilution and Etest (R) agar gradient diffusion methods. $J$. Antimicrob. Chemother. Doi: 10: 1093/jac/dkm213.

18. Mammeri, H.; Bellais, S.; Nordmann, P. (2002). Chromosomeencoded beta-lactamases TUS-1 and MUS-1 from Myroides odoratus and Myroides odoratimimus (formerly Flavobacterium odoratum), new members of the lineage of molecular subclass B1 metalloenzymes. Antimicrob. Agents Chemother., 46 (11), 35613567 .

19. Maneerat, S.; Bamba, T.; Harada, K.; Kobayashi, A.; Yamada, H.; Kawai, F. (2006). A novel crude oil emulsifier excreted in the culture supernatant of a marine bacterium, Myroides sp. strain SM1. Appl. Microbiol. Biotechnol., 70 (2), 254-259.

20. Maurin, M.; Delbano, J.N.; Mackaya, L.; Colomb, H.; Guier, C.; Mandjee, A.; Recule, C.; Croize J. (2007). Human infection with Schineria larvae. Emerg. Infect. Dis., 13 (4), 657-659.

21. Nadjar, D.; Labia, R.; Cerceau, C.; Bizet, C.; Philippon, A.; Arlet, G. (2001). Molecular characterization of chromosomal class C betalactamase and its regulatory gene in Ochrobactrum anthropi. Antimicrob. Agents Chemother., 45 (8), 2324-2330.

22. National Committee for Clinical Laboratory Standards. (2005) Performance Standards for antimicrobial susceptibility testing; Fifteenth Informational Supplement, v.25, n.1, M100-S14.

23. Pidiyar, V.; Kaznowski, A.; Narayan, N.B.; Patole, M.; Shouche, Y.S (2002). Aeromonas culicicola sp. nov., from the midgut of Culex quinquefasciatus. Int. J. Syst. Evol. Microbiol., 52 (Pt 5), 17231728.

24. Rangrez, A.Y.; Dayananda, K.M.; Atanur, S.; Joshi, R.; Patole, L.M.S.; Shouche, Y.S. (2006). Detection of Conjugation Related Type Four Secretion Machinery in Aeromonas culicicola. PLoS One, 1 (1), e115.

25. Rodrigues, A.P.; Holanda, A.R.; Lustosa, G.P.; Nobrega, S.M.; Santana, W.J.; Souza, L.B.; Coutinho, H.D. (2006). Virulence factors and resistance mechanisms of Serratia marcescens. Acta Microbiol. Immunol. Hung., 53 (1), 89-93.

26. Saidijam, M.; Benedetti, G.; Ren, Q.; Xu, Z.; Hoyle, C.J.; Palmer, S.L.; Ward, A.; Bettaney, K.E.; Szakonyi, G.; Meuller, J.; Morrison, S.; Pos, M.K.; Butaye, P.; Walravens, K.; Langton, K.; Herbert, R.B.; Skurray, R.A.; Paulsen, I.T.; O'reilly, J.; Rutherford, N.G.; Brown, M.H.; Bill, R.M.; Henderson, P.J. (2006). Microbial drug efflux proteins of the major facilitator superfamily. Curr. Drug Targets., 7 (7), 793-811.

27. Saitou, N.; Nei, M. (1987). The neighbor-joining method: a new method for reconstructing phylogenetic trees. Mol. Biol. Evol., 4, 406-425.

28. Sambrook, J.; Fritsch, E.F.; Maniatis T. (1989). Molecular Cloning: A Laboratory Manual. Cold Spring Harbor, NY: Cold Spring Harbor Laboratory Press.

29. Sato, K.; Fujii, T.; Okamoto, R.; Inoue M.; Mitsuhashi, S. (1985). Biochemical properties of â-lactamase produced by Flavobacterium odoratum. Antimicrob. Agents Chemother., 27, 612-614.

30. Seshadri, R.; Joseph, S.W.; Chopra, A.K.; Sha, J.; Shaw, J.; Graf, J.; Haft, D.; Wu, M.; Ren, Q.; Rosovitz, M.J.; Madupu, R.; Tallon, L.; Kim, M.; Jin, S.; Vuong, H.; Stine, O.C.; Ali, A. Horneman, A.J.; Heidelberg, J.F. (2006). Genome sequence of Aeromonas hydrophila ATCC 7966T: jack of all trades. J. Bacteriol., 188 (23), 8272-8282.

31. Spiteller, D.; Dettner, K.; Bolan, W. (2000). Gut bacteria may be involved in interactions between plants, herbivores and their predators: microbial biosynthesis of N-acylglutamine surfactants as elicitors of plant volatiles. Biol. Chem., 381 (8), 755-762.

32. Thompson, J.D.; Higgins, D.G.; Gibson, T.J. (1994). CLUSTAL W: improving the sensitivity of progressive multiple sequence alignment through sequence weighting, position-specific gap penalties and weight matrix choice. Nucleic Acids Res., 22, 4673-4680. 
33. Tsakris, A.; Ikonomidis, A.; Spanakis, N.; Poulou, A.; Pournaras, S. (2007). Characterization of In3Mor, a new integron carrying VIM1 metallo-beta-lactamase and sat1 gene, from Morganella morganii. J. Antimicrob. Chemother., 59 (4), 739-741.

34. Vancanneyt, M.; Segers, P.; Torck, U.; Hoste, B.; Bernardet, J.F.; Vandamme, P.; Kersters, K. (1996). Reclassification of Flavobacterium odoratum (Stutzer 1929) strains to a new genus, Myroides, as Myroides odoratus comb. nov. and Myroides odoratimimus sp. nov. Int. J. syst. Bacteriol., 46, 926-932.

35. Xu, D.; Zhou, Y.; Xie, D.; Guo, H. (2005). Antibiotic binding to monozinc CphA beta-lactamase from Aeromonas hydropila: quantum mechanical/molecular mechanical and density functional theory studies. J. Med. Chem., 48 (21), 6679-6689.

36. Yagci, A.; Cerikcioglu, N.; Kaufmann, M.E.; Malnick, H.; Soyletir, G.; Babacan, F.; Pitt, T.L. (2000). Molecular typing of Myroides odoratimimus (Flavobacterium odoratum) urinary tract infections in a Turkish hospital. Eur. J. Clin. Microbiol. Infect. Dis., 19 (9), 731-732.

37. Yoon, J.; Maneerat, S.; Kawai, F.; Yokota, A. (2006). Myroides pelagicus sp. nov., isolated from seawater in Thailand. Int. J. Syst. Evol. Microbiol., 56 (Pt 8), 1917-1920. 